\title{
POTENSI ENERGI ARUS LAUT UNTUK PEMBANGKIT TENAGA LISTRIK DI PULAU-PULAU KECIL (Studi :Pulau Mantang di Bintan, Pulau Abang di Batam, dan Pulau Sugi di Karimun, Propinsi Kepulauan Riau)
}

\author{
POTENTIAL ENERGY OF OCEAN CURRENT FOR ELECTRIC POWER GENERATOR IN \\ SMALL ISLAND (Study: Mantang Island-Bintan, Abang Island-Batam and Sugi Island-Karimun \\ Riau Islands Province)
}

\author{
Yulhendri Suryansyah \\ Pusat Pengkajian dan Perekayasaan Teknologi Kelautan dan Perikanan \\ yulsurm@kkp.go.id
}

Diterima tanggal: 6 Februari 2013, diterima setelah perbaikan: 12 April 2013, disetujui tanggal: 22 April 2013

\begin{abstract}
ABSTRAK
Energi arus laut merupakan sumber yang konsisten dari energi kinetik dapat diprediksi akan sangat menarik untuk diatur sebagai manajemen jaringan pembangkit listrik. Permasalahan yang dihadapi kepulauan Riau sebagai pulaupulau kecil adalah keterbatasan energi listrik yang tidak terjangkau oleh listrik PLN. Berdasarkan Analisis dan pengukuran arus dan potensi daya listrik di tiga buah Pulau yaitu Pulau Sugi, Pulau Abang dan Pulau Mantang, dapat disimpulkan bahwa Pulau Sugi memiliki potensi yang lebih besar daripada ke dua pulau lainnya untuk dapat dikembangkan dan dibuat pembangkit listrik tenaga arus dengan potensi daya rata-rata sebesar 15567,19 watt/h.
\end{abstract}

Kata Kunci: Energi Arus, Kepulauan Riau, Keterbatasan, Pulau Sugi

\section{ABSTRACT}

Ocean current energy as a reliable kinetic energy can be predicted to be very interesting to set up a power generator network management. Over a years, Riau archipelago that consist of several small islands are faced electricity susceptibility due to the archipelago was not covered by the Indonesia National Electric Company (PLN). Base on measurement and potential power analysis on three islands namely Sugi Island, Abang Island and Mantang Island, It can be concluded that Sugi Island has more viable in order to develop and build ocean current electric generator with potential power of 15567,19 watt/h.

Keywords: Ocean current, Riau Islands, limitation, Sugi Island.

\section{PENDAHULUAN}

Perkembangan teknologi pemanfaatan energi laut khususnya arus laut sebagai energi baru terbarukan di dunia saat ini berkembang dengan pesat, seiring dengan meningkatnya tuntutan akan kebutuhan energi listrik masyarakat kawasan pesisir serta semakin maraknya isu pemanasan global yang mendorong untuk membatasi penggunaan bahan bakar hidrokarbon.

Prinsip yang dikembangkan pada aplikasi teknologi pemanfaatan energi dari laut adalah melalui konversi tenaga kinetik masa air laut menjadi tenaga listrik. Pada dasarnya, arus laut merupakan gerakan horizontal massa air laut, sehingga arus laut memiliki energi kinetik yang dapat digunakan sebagai tenaga penggerak rotor atau turbin pembangkit listrik. Selain itu, arus laut ini juga menarik untuk dikembangkan sebagai pembangkit listrik karena sifatnya yang relatif stabil dan dapat diprediksi karakteristiknya.

Pengembangan teknologi ekstraksi energi arus laut ini dilakukan dengan mengadopsi prinsip teknologi energi angin yang telah lebih dulu berkembang, yaitu dengan mengubah energi kinetik arus laut menjadi energi rotasi dan energi listrik.

Energi arus pasang surut menyajikan salah satu bentuk yang muncul paling menarik dari energi 
terbarukan. Arus pasang surut, tidak seperti energi terbarukan bentuk lain, merupakan sumber energi yang konsisten disebabkan oleh siklus pasang surut yang dipengaruhi oleh fase bulan. Dibandingkan dengan energi angin dan tenaga surya adalah matahari tidak selalu bersinar dan angin tidak selalu bertiup. Sumber-sumber energi terbarukan sering membutuhkan cadangan dari bentuk-bentuk tradisional pembangkit listrik, tapi pasang surut yang dapat diprediksi akan sangat menarik untuk diatur sebagai manajemen jaringan pembangkit listrik. Turbin pasang surut dipasang di dasar laut di lokasi dengan kecepatan tinggi saat pasang surut, atau kuat arus laut terus menerus dan merubah energi dari air yang mengalir.

Menurut Suryansyah (2005) teknologi ideal yang akan diterapkan di pulau-pulau kecil memiliki kriteria sebagai berikut: (1) ketersediaan tenaga terampil untuk mengoperasikan teknologi, (2) dapat diterima oleh masyarakat setempat dan tidak bertentangan dengan adat atau peraturaran desa, (3) hemat energi, (4) ketersediaan bahan baku (material) teknologi di pulau atau setidaknya lebih mudah bila diimpor dari luar pulau, (5) ramah lingkungan, (7) pemberian teknologi berbasis pada kebutuhan rnasyarakat, (8) pengelotaan manajemen teknologi, (9) pemeliharaan perawatan teknologi dapat dilakukan secara lokal, (10) ada kebijakan peraturan lokal dalam penggunaan teknologi.

Kawasan Minapolitan merupakan kawasan pembangunan ekonomi kelautan dan perikanan berbasis kawasan dengan prinsip terintegrasi, efisiensi, kualitas dan percepatan. Kawasan Minapolitan di Provinsi Kepulauan Riau terutama dikembangkan untuk budidaya rumput laut, meliputi : Pulau Mantang di Bintan, Pulau Abang di Batam, dan Pulau Sugi di Karimun. Berdasarkan rencana pengembangan perikanan budidaya di Provinsi Kepulauan Riau, ketiga daerah tersebut memiliki potensi utnuk pengembangan kegiatan budidaya perikanan.

Luas wilayah Provinsi Kepulauan Riau adalah 251.810,71 $\mathrm{Km}^{2}$. Namun sebagai daerah kepulauan, luas lautan yang dimiliki Provinsi Kepulauan Riau sekitar 95,79 persen atau seluas 241.215,30 Km2. Sedangkan sisanya sebesar 4,21 persen atau seluas $10.595,41 \mathrm{Km}^{2}$ adalah daratan.
Kabupaten Karimun memiliki daratan terbesar dengan persentase sebesar 27,12 persen dari luas daratan Provinsi Kepulauan Riau atau seluas 2.873,20 Km2, diikuti Lingga 19,99 persen $(2.117,72 \mathrm{Km} 2)$ dan Bintan sebesar 18,36 persen (1.946,13 Km2). (BPS Kepri 2012).

Menurut Suryansyah (2005) permasalahan umum yang dihadapi kepulauan Riau adalah keterbatasannya sebagai pulau-pulau kecil terutama masalah air bersih dan energi listrik yang tidak terjangkau oleh jaringan listrik PLN. Kondisi yang ada sekarang adalah pembangkit listrik menggunakan genset berbahan bakar solar yang biaya operasionalnya tinggi dan mesin genset yang sering rusak, sehingga sering terjadi pemadaman pemadaman listrik. Adanya Pembangkit listrik tenaga arus laut diharapkan dapat menjadi solusi dari masalah diatas.

Tulisan ini dibuat dengan tujuan untuk menginformasikan potensi daya listik yang dimiliki di pulau-pulau kecil di propinsi Kepulauan Riau yang memiliki potensi untuk pengembangan pembangkit listrik tenaga arus laut.

\section{BAHAN DAN METODE}

Pemilihan Propinsi Kep. Riau sebagai lokasi kegiatan didasari oleh roadmap Penelitian Energi Arus Laut Indonesia yang diarahkan ke Propinsi Kepulauan Riau (Sumber: PPGL, 2010).

Data primer diperoleh dari citra satelit dan survei lapangan (ground truthing) sedangkan data sekunder dilakukan melalui penelusuran terhadap data/dokumen penunjang yang berasal dari hasil kajian atau penelitian sebelumnya atau data dari instansi yang terkait, seperti Dinas HidroOseanografi, Dinas Kelautan dan Perikanan, dan Bappeprop Kepulauan Riau.

Pengumpulan data dilaksanakan pada bulan Maret hingga November 2012 di Kota Tanjung Pinang Propinsi Kepulauan Riau. Data pengukuran diperoleh dari pengukuran dengan metode ADCP dan dianalisis dengan model MEC. 


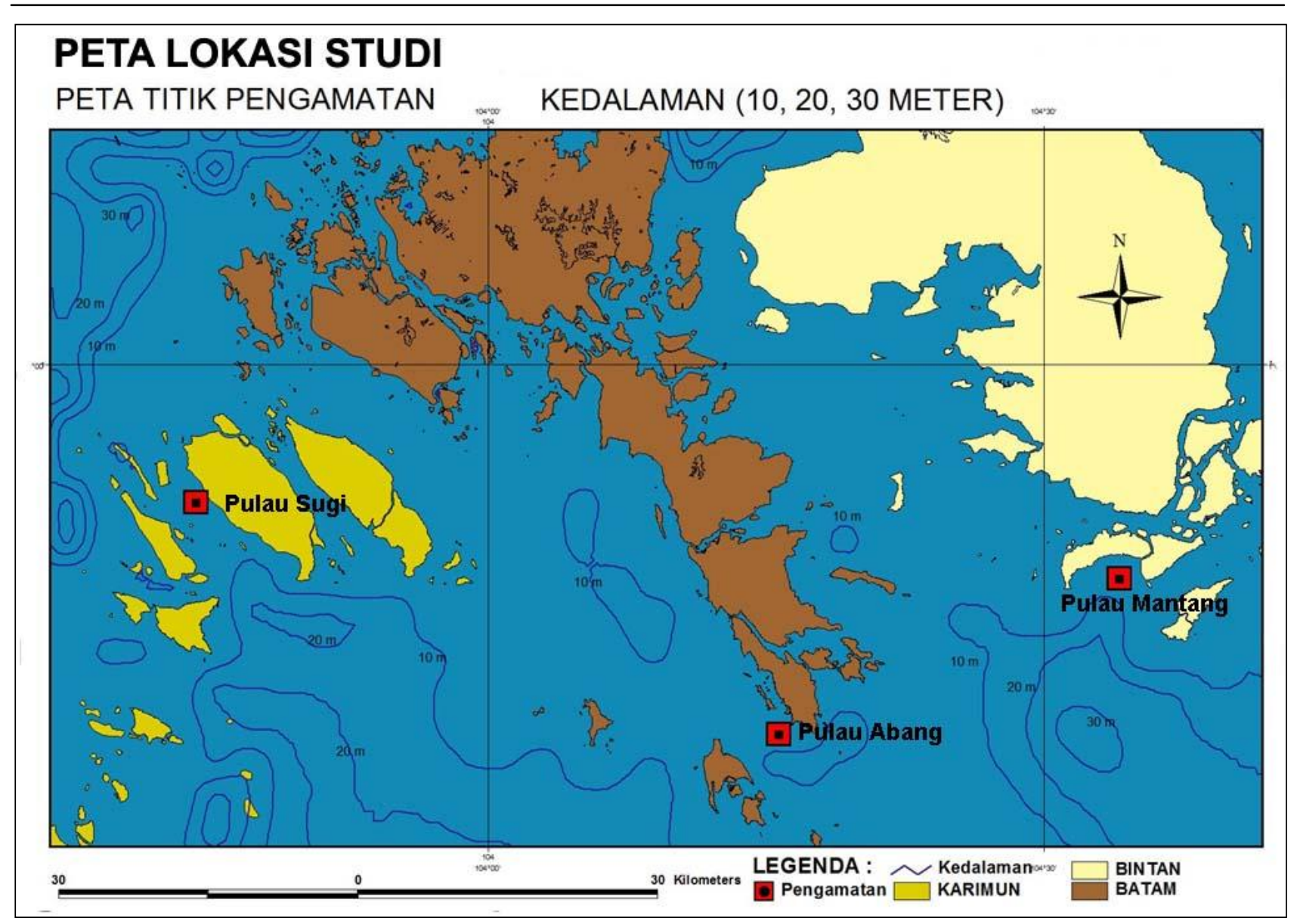

Gambar 1. Peta Lokasi Studi (Sumber: Bappeda Kep. Riau, 2011))

(Studies Location Map)

Data arus diperoleh dari pengamatan selama 6 hari dengan menggunakan ADCP (Acoustic Doppler Current Profiler), Selain itu, data arus didukung dengan data time series selama 4 tahun mulai dari bulan Januari sampai dengan Desember dari Badan Meteorologi Klimatologi dan Geofisika. Data Batimetri (kedalaman) diamati dengan Echosounder dan didukung data sekunder yang diperoleh dari Dihidros.

Pengukuran arus laut dilakukan di 3 wilayah perairan potensial dengan current meter jenis ADCP Argonaut XR Sontex. Selain arus laut, ADCP jenis ini juga dipakai untuk menentukan temperatur dan tinggi gelombang. Pengukuran kedalaman dengan menggunakan alat echosounder Garmin GPS MAP 470 Yang yang dilakukan terutama pada saat pemasangan ADCP. Pemetaan batimetri didukung dengan data dari HGT-SRTM
(Shuttle Radar Topography Mission) pada Tahun 2004.

Menurut Azis (2006) untuk meghitung potensi energi arus di lokasi pengukuran dapat menggunakan analisis potensi daya dengan persamaan Kobalt sebagai berikut:

$$
\mathrm{P}=0,5 \rho \times \mathrm{S} \times \mathrm{H} \times \mathrm{V}^{3}
$$

Dimana:

$$
\begin{aligned}
& \mathrm{P}=\text { Energi listrik yang dihasilkan }(\mathrm{kW}) \\
& \rho=\text { Berat jenis air laut }(1.025) \\
& \mathrm{V}=\text { Kecepatan arus }(\mathrm{m} / \mathrm{s}) \\
& \mathrm{S}=\text { Tinggi Blade }=40 \mathrm{~m} 2 \\
& \mathrm{H}=\text { Koefisien untuk turbin Kobold }=50 \%
\end{aligned}
$$




\section{HASIL DAN PEMBAHASAN}

Pasut di perairan Pulau Batam dan sekitarnya dapat dikategorikan berjenis campuran (mixed pattern) cenderung ganda (semidiurnal pattern). Rekaman bulanan pasut selama September 2011 seperti dipelihatkan pada (Gambar 2). menunjukkan fluktuasi jenis pasut campuran (mixed tidal) yang khas.

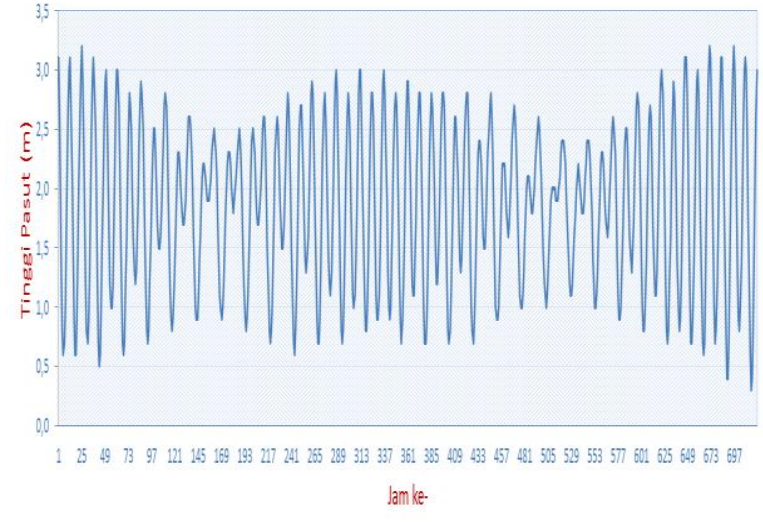

Gambar 2. Fluktuasi pasut (tidal fluctuations)

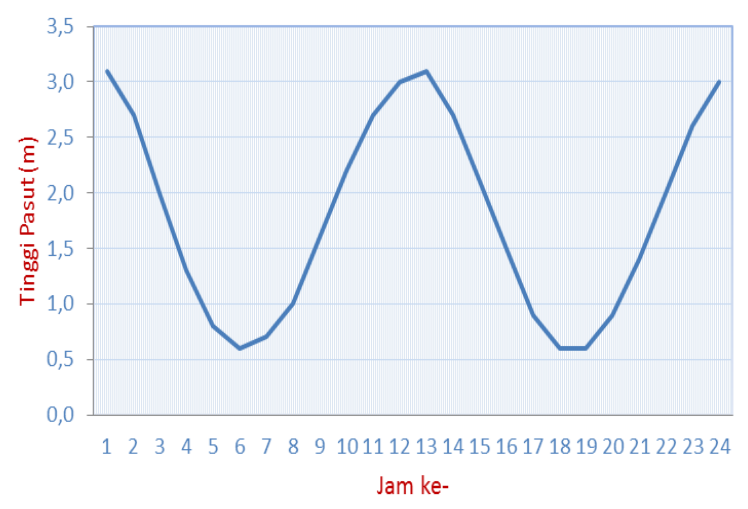

Gambar 3. contoh pola semidiurnal (example of semidiurnal pattern)

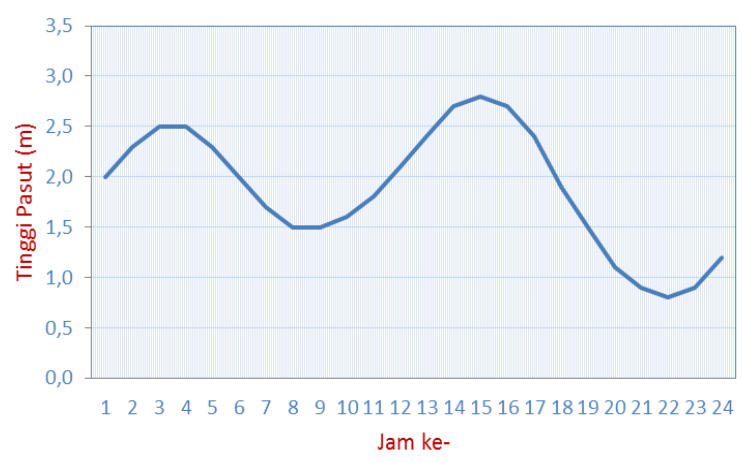

Gambar 4. contoh pola campuran (example of a mixed pattern)
Dalam pilah harian yang diambil pada tanggal 1 September (Gambar 3), pasut memiliki pola semidiurnal dengan dua kali pasang dan dua kali surut. Pasang pertama terjadi pada 01.00 saat tinggi pasut tercatat setinggi $3,1 \mathrm{~m}$, lima jam kemudian pasut mencapai surut senilai $0,6 \mathrm{~m}$; pada pukul 13.00 pasut kembali pasang setinggi 3,1 m, dan kemudian mencapai ketinggian $0,6 \mathrm{~m}$ yang menandai terjadinya surut ke-2 pada pukul 19.00.

Gambar 4 menunjukan pola campuran (mixed pattern) selama September yang dicontohkan oleh rekaman pasut pada tanggal 5 September. Pada tanggal tersebut juga terjadi dua kali pasang dan dua kali surut, namun dengan capaian tinggi yang berbeda. Pasang pertama tanggal tersebut tercatat setinggi $2,5 \mathrm{~m}$ yang terjadi pada pukul 03.00, sedangkan pasang kedua berlangsung pada pukul 15.00 saat capaian tinggi muka laut menyentuh 2,8 $\mathrm{m}$; sementara itu surut pertama terjadi pada pukul 09.00 dengan senilai $1,5 \mathrm{~m}$, dan surut kedua senilai $0,8 \mathrm{~m}$ terjadi pada pukul 22.00. Kedua pola tersebut merentang di sepanjang september dengan perselingan yang didominasi oleh semidiurnal.

Pada September pasang tertinggi tercatat sebesar 3,2 $\mathrm{m}$, surut terendah $0,3 \mathrm{~m}$ dengan rataan tinggi pasut $1,8 \mathrm{~m}$. Dengan demikian tunggang pasut di perairan Pulau Batam, bila merujuk pada rekaman September, adalah sebesar 2,9 m .

\section{Karakteristik Arus Regional Kepulauan Riau}
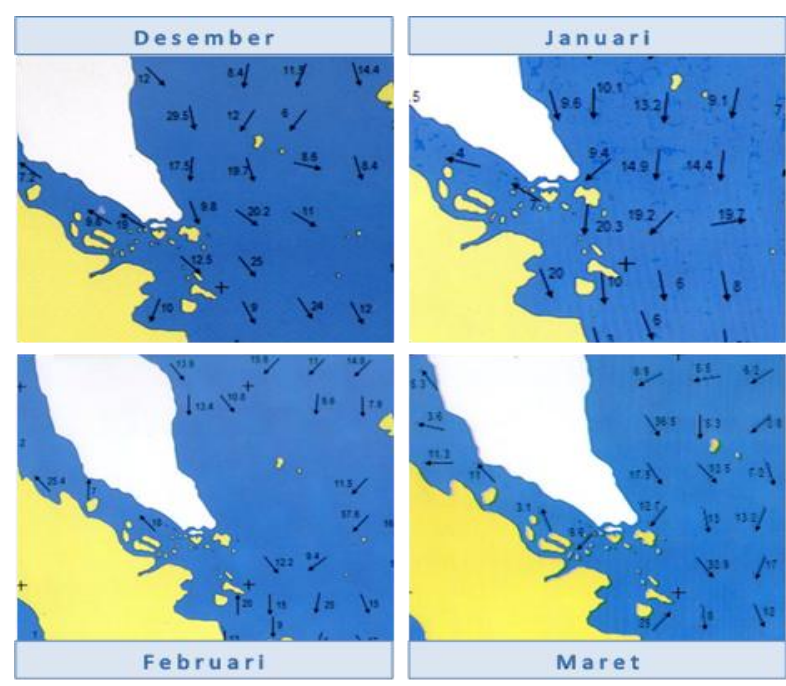

Gambar 5. Pola Arus Regional Kepulauan di Riau pada Musim Barat

Gambar. 5 menunjukkan bahwa pada musim barat (Desember-Maret) Arus memasuki perairan Pulau 
Batam dengan kecepatan yang bervariasi antara 9,4 hingga $12,7 \mathrm{mil} / \mathrm{hari}$. Arus yang meningggalkan area perairan Pulau Batam menuju ke Selat Malaka bergerak dengan keepatan 7 mil/hari (Januari) hingga $19 \mathrm{mil} /$ hari (Desember); Sementara arus yang menuju ke sisi timur Riau-Jambi bergerak dengan kecepatan hingga 20,3 mil/jam pada Januari, sedangkan pada Desember hanya 12,5 $\mathrm{mil} / \mathrm{jam}$.
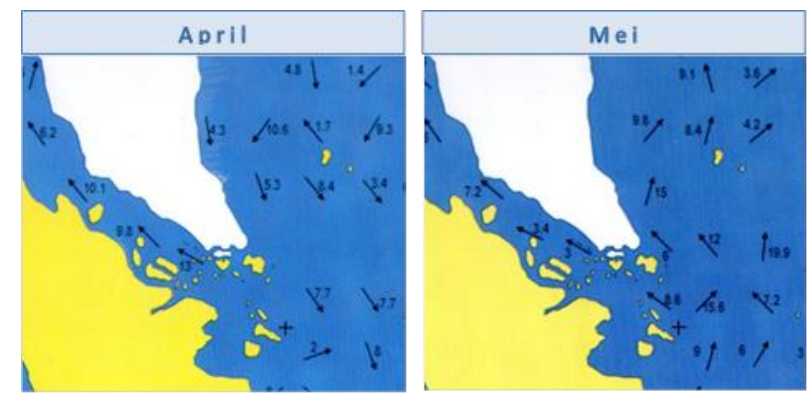

Gambar 6. Pola Arus Regional Kepulauan di Riau pada Musim Pancaroba Awal (Sumber : Peta Arus Dinas Hidro Oseanografi, Jakarta)

Gambar. 6 menunjukkan bahwa selama musim pancaroba awal (April-Maret) pola arus mulai mengalami perubahan. Bila pada April arus perairan Pulau Batam masih menunjukkan pola arah arus musim barat dengan gerakan aliran dari perairan sisi timur Malaysia (kecepatan 5,3 mil/hari) memasuki Selat Malaka (kecepatan 13 mil/hari), maka sebulan berikutnya arah arus mengalami perubahan arah. Pada bulan Mei Arus bergerak dari tenggara-selatan area Selat Karimata dengan kecepatan 6-8,6 mil/hari.
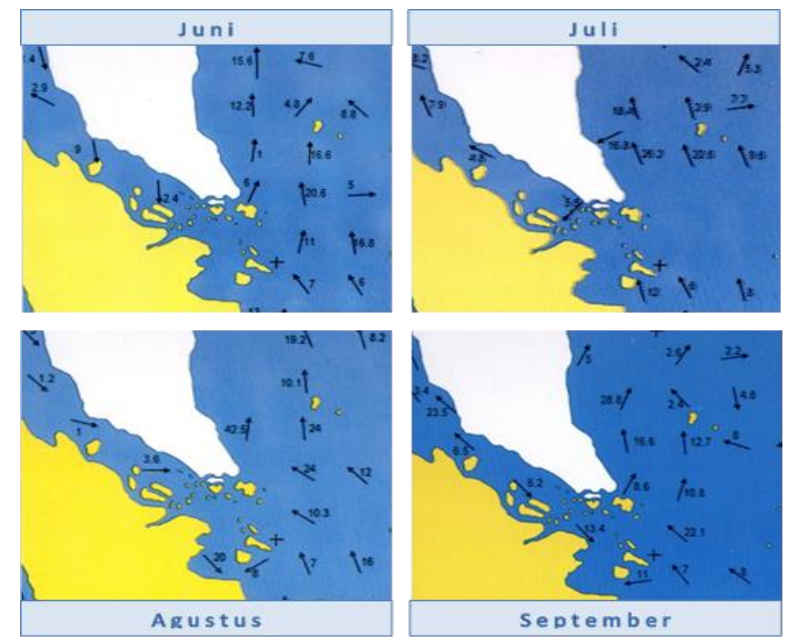

Gambar 7. Pola Arus Regional Kepulauan di Riau pada Musim Timur
Gambar 7 menunjukkan bahwa selama musim timur, seretan arus dari Laut Jawa yang bergerak ke barat terdorong ke utara saat memasuki Selat Karimata dan menjadi sumber aliran arus di perairan Pulau Batam. Arus yang memasuki perairan Pulau Batam dengan kecepatan 10,3 mil/hari (Agustus) hingga 33,1 mil/hari (September). Pola balikan arus secara umum juga terlihat di Selat Malaka. Pada periode ini aliran arus relatif bergerak dari Selat Malaka menuju perairan Pulau Batam dengan kecepatan 2,4 mil/hari pada Juni hingga $8,2 \mathrm{mil} / \mathrm{hari}$ pada September.
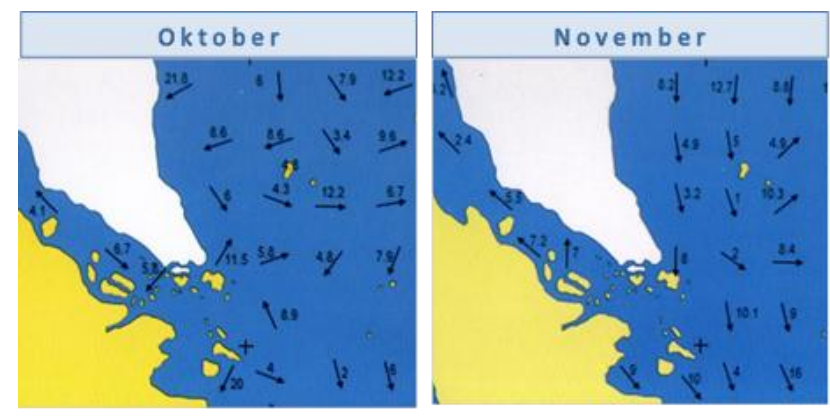

Gambar 8. Pola Arus Regional Kepulauan di Riau pada Musim Pancaroba Akhir

Gambar 8 menunjukkan bahwa pada bulan November arus sisi timur Malaysia memasuki perairan Pulau Batam dengan kecepatan 8 mil/hari, kemudian bergerak menuju Selat Malaka melalui Selat Singapura dengan kecepatan 7 mil/hari.

Pada Oktober, yang lebih dekat dengan musim timur dibandingkan dengan November, pola arus perairan Pulau Batam dan sekitarnya belum berubah sepenuhnya seperti pada November yang lebih mendekati musim barat. Arus datang dari Selat Karimata, dengan kecepatan 8,9 mil/hari. Aliran arus selanjutnya terpecah menuju ke perairan Laut Cina Selatan dan Selat Malaka masing-masing dengan kecepatan 11,5 mil/hari dan $5,8 \mathrm{mil} / \mathrm{hari}$.

\section{Analisis Karakteristik Arus Pulau Mantang}

Arus di perairan Mantang bergerak (43\%) menuju ke timur laut dengan kecepatan yang relatif rendah. Sekitar $40 \%$ arus timur laut mengalir dengan kecepatan $\leq 2,5 \mathrm{~cm}$, sisanya bergerak dengan kecepatan $2,5-5 \mathrm{~cm} / \mathrm{s}$.). Arus dominan berikutnya mengalir ke barat laut (37\%) dengan kecepatan yang sama. Aliran arus juga bergerak ke utara, 
selatan dan barat daya dengan frekuensi $<10 \%$ engan kecepatan $\leq 2,5 \mathrm{~cm}$.

Secara keseluruhan arus 90,5\% mengalir dengan kecepatan $\leq 2,5 \mathrm{~cm}$, dan hanya $9,5 \%$ yang bergerak dengan kecepatan 2,5-5 cm/s (Gambar 9).
Dibandingkan dengan dua perairan studi lain, arus di perairan Mantang tergolong yang paling lemah. Arus maksimum hanya mencapai $8,75 \mathrm{~cm} / \mathrm{s}$, dengan rataan kecepatan arus $1,50 \mathrm{~cm} / \mathrm{s}$ dan arus minimumnya $0,08 \mathrm{~cm} / \mathrm{s}$.
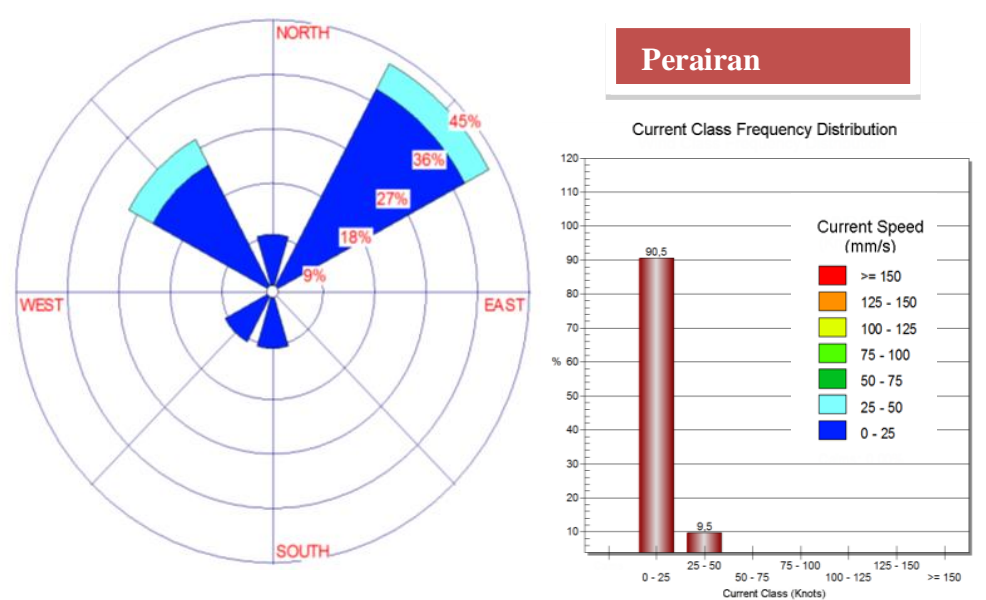

Gambar 9. Pola arus permukaan di perairan Mantang (Current patterns in the surface waters of MantangIsland)

\section{Analisis Karakteristik Arus Pulau Abang}

Pola arus di perairan Pulau Abang menegaskan kuatnya arus barat daya yang mencapai sekitar $50 \%$ dari frekuensi perekaman (Gambar 10). Arus tersebut tergolong sebagai arus lemah dari keseluruhan arus yang tercatat, yakni hanya berkecepatan kurang dari $2,5 \mathrm{~cm} / \mathrm{s}$. Arus dominan berikutnya adalah arus timur yang mengalir dengan kecepatan yang sama. Arus ini terekam sebesar sekitar $15 \%$ dari seluruh frekuensi perekaman. Sebanyak $83,3 \%$ arus yang mengalir di perairan Pulau Abang melaju dengan kecepatan $\leq 2,5 \mathrm{~cm} / \mathrm{s}$.
Pola arah arus yang lain ditemukan bergerak ke barat, barat daya, selatan dan tenggara dengan frekuensi masing-masing di bawah 10\%. Arus barat daya tercatat memiliki kecepatan yang lebih besar, yakni 7,5-10 cm/s, sedangkan arus tenggara $(8,3 \%)$ arus yang mengalir paling kuat di perairan ini mencapai kecepatan 12,5-15 cm/s. Rataan kecepatan arus di perairan pulau Abang mencapai $1,45 \mathrm{~cm} / \mathrm{s}$ dengan kecepatan maksimum 12,97 cm/s dan kecepatan minimum $0,02 \mathrm{~cm} / \mathrm{s}$.
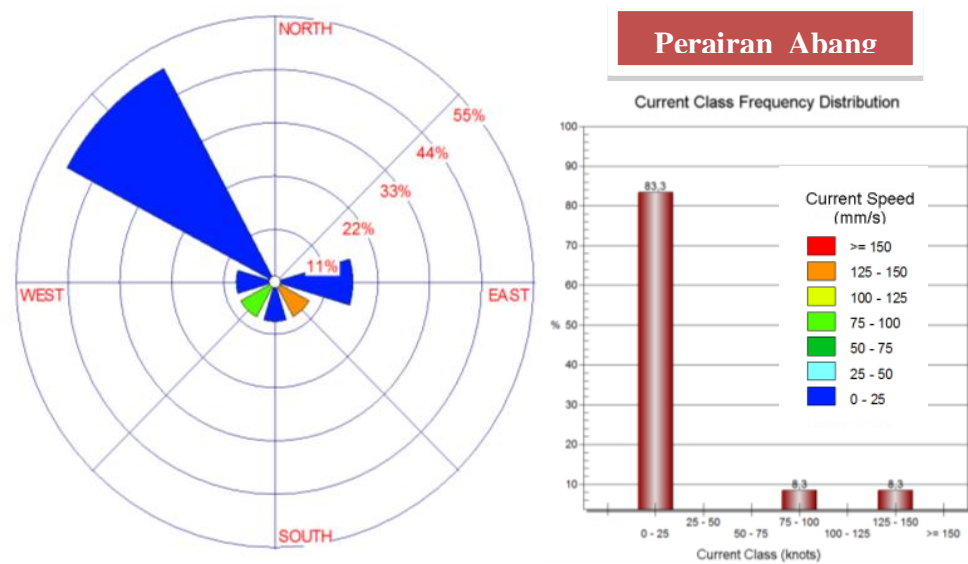

Gambar 10. Pola arus permukaan di perairan Pulau Abang (Current patterns in the surface waters of Abang Island) 
Analisis Karakteristik Arus Pulau Sugi (Moro) Di perairan Pulau Sugi secara umum arusnya lebih kuat dibandingkan dengan arus di perairan Pulau Abang (Gambar 10), meskipun capaian terbesarnya hanya 5-7,5 cm/s. Arus di perairan Pulau Sigi, seperti ditampilkan pada (Gambar 11), didominasi oleh arus berkecepatan $2,5-5 \mathrm{~cm} / \mathrm{s}(63,6 \%)$.
Arus terekam mengalir secara dominan ke utara (sekitar 45\%) dan timur laut (sekitar 25\%). Arus terkuat sebesar 5-7,5 cm/s ditemukan mengalir ke timur laut dengan frekuensi $9,1 \%$. Rataan kecepatan arus perairan ini mencapat $2,93 \mathrm{~cm} / \mathrm{s}$ dengan capaian maksimum $5,74 \mathrm{~cm} / \mathrm{s}$ dan capaian minimum $0,21 \mathrm{~cm} / \mathrm{s}$.
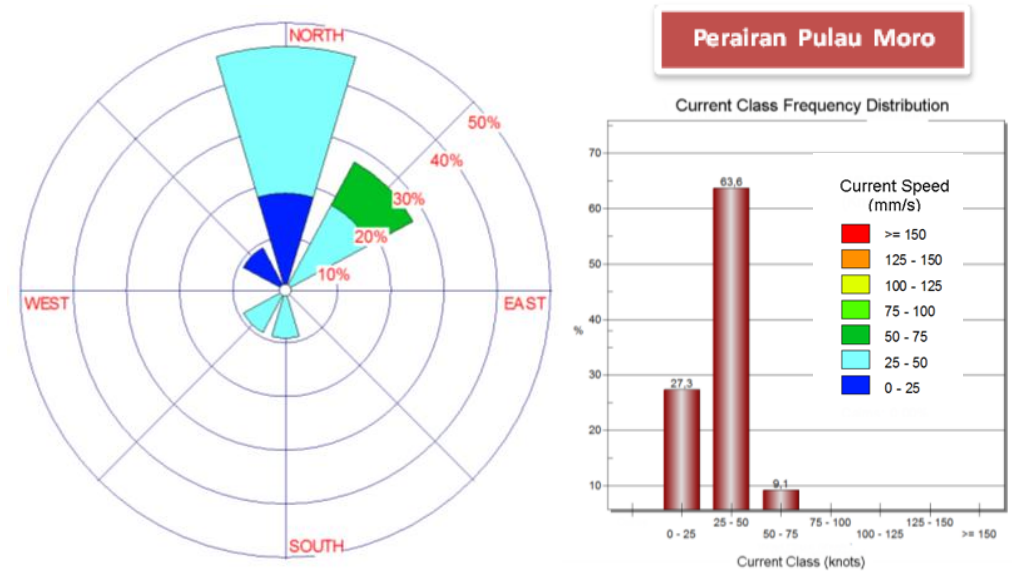

Gambar 11. Pola arus permukaan di perairan Pulau Sugi (Moro) (Current patterns in the surface waters of Sigi Island)

Tabel 1. Perhitungan Potensi Daya Listrik di Lokasi Studi

\begin{tabular}{|c|c|c|c|c|c|c|c|}
\hline No & Pulau & Kecepatan Arus (m/s) & $\mathbf{V}$ & $\rho$ & $\mathbf{S}$ & $\mathbf{H}$ & Watt/Hour \\
\hline \multirow{3}{*}{1} & \multirow{3}{*}{ SUGI } & Maksimum & 0.075 & 1.025 & 40 & 0.5 & 15567.19 \\
\hline & & Rata-rata & 0.0293 & 1.025 & 40 & 0.5 & 928.17 \\
\hline & & Minimum & 0.0021 & 1.025 & 40 & 0.5 & 0.34 \\
\hline \multirow{3}{*}{2} & \multirow{3}{*}{ ABANG } & Maksimum & 0.1297 & 1.025 & 40 & 0.5 & 80509.35 \\
\hline & & Rata-rata & 0.0145 & 1.025 & 40 & 0.5 & 112.49 \\
\hline & & Minimum & 0.0002 & 1.025 & 40 & 0.5 & 0.00 \\
\hline \multirow{3}{*}{3} & \multirow{3}{*}{ MANTANG } & Maksimum & 0.0875 & 1.025 & 40 & 0.5 & 24720.12 \\
\hline & & Rata-rata & 0.015 & 1.025 & 40 & 0.5 & 124.54 \\
\hline & & Minimum & 0.0008 & 1.025 & 40 & 0.5 & 0.02 \\
\hline
\end{tabular}

Berdasarkan Tabel 1 terlihat bahwa potensi daya maksimum terdapat di pulau Abang dengan potensi daya $80509.35 \mathrm{w} / \mathrm{h}$ akan tetapi secara rata-rata hanya memiliki potensi daya $112.49 \mathrm{w} / \mathrm{h}$. Pulau Sugi secara rata-rata memiliki potensi daya sebesar $928.17 \mathrm{w} / \mathrm{h}$ walaupun potensi daya maksimumnya lebih kecil dari daya maksimum di pulau Abang yaitu sebesar $15567.19 \mathrm{w} / \mathrm{h}$.

Pulau Sugi lebih potensial pengembangan pembangkit listrik tenaga arus laut, dengan potensi daya rata-rata sebesar $15567.19 \mathrm{w} / \mathrm{h}$. 
Salah satu tipe turbin arus laut yang direkomendasikan di kawasan pulau-pulau kecil adalah Sabella, karena ukuran turbinnya bisa disesuaikan dengan kondisi perairan sekitar (P3TKP, 2012).

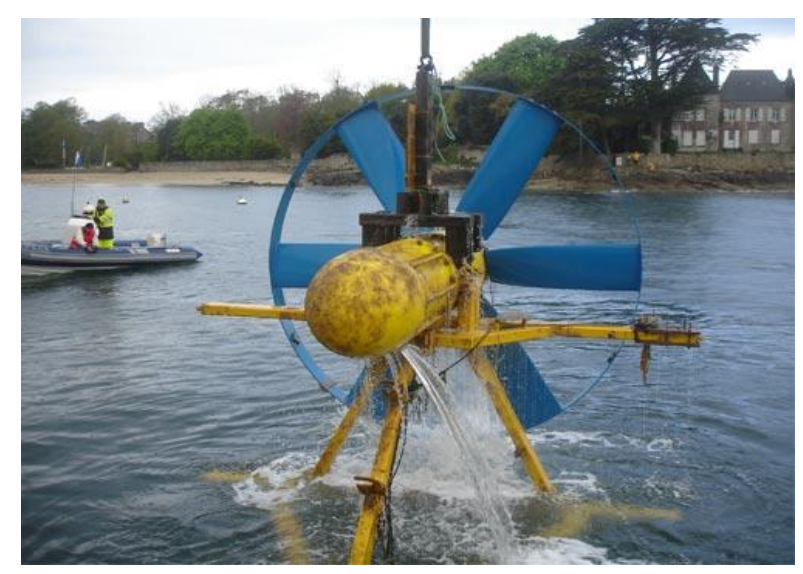

Gambar 12. Turbin Sabella (Sumber: www.Sabella.fr)

Pembangkit listrik yang akan dipasang menggunakan teknik marine current farm yaitu istilah untuk menggambarkan suatu area dengan susunan beberapa buah turbin sebagai upaya untuk mengubah energi arus ke energi kinetik secara optimum. Turbin dapat dipasang pada dasar laut atau mengapung. Jarak horizontal setiap turbin pada tiap baris dan jarak antar baris tergantung pada keperluan pemeliharaan, sesuai prosedur pemasangan dan juga pengaruh aliran air (P3TKP, 2012).

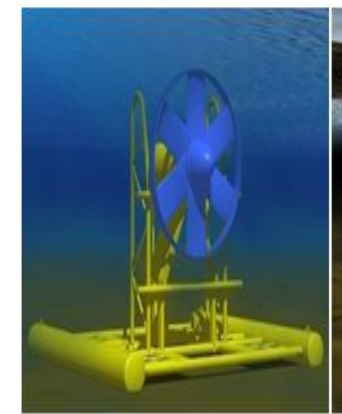

"Sabella D10"

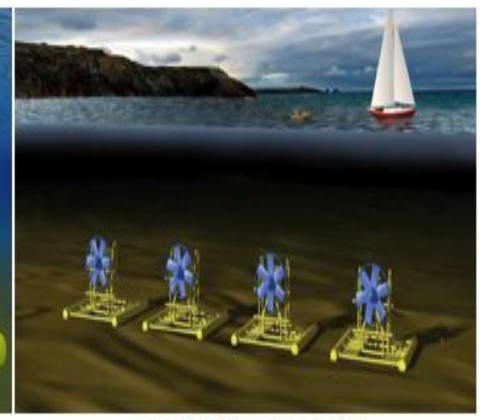

Ferme hydrolienne "Eussabella"
Gambar 13. Turbin Sabella (Sumber: www.Sabella.fr)

\section{KESIMPULAN DAN SARAN}

Berdasarkan hasil data diatas maka dapat disimpulkan bahwa Pulau Sugi merupakan kawasan yang paling layak untuk implementasi pembangkit listrik tenaga arus laut. Hal ini dikarenakan rataan kecepatan arus perairan ini yang mencapai $2,93 \mathrm{~cm} / \mathrm{s}$ dengan capaian maksimum $5,74 \mathrm{~cm} / \mathrm{s}$ dan capaian minimum 0,21 $\mathrm{cm} / \mathrm{s}$ dengan potensi daya listrik rata-rata mencapai $15567.19 \mathrm{w} / \mathrm{h}$.

Jenis turbin sabella direkomendasikan untuk dibangun pada kawasan pulau kecil karena dapat menyesuaikan dengan kondisi lingkungan dan daya listrik yang dihasilkan dioptimalkan dengan teknik marine current farm.

\section{DAFTAR PUSTAKA}

Azis. A. 2006. Studi Pemanfaatan Energi Listrik Tenaga Arus Laut di Selat Alas Kabupaten Lombok, NTB. Jurusan Teknik Elektro-FTI, Institut Teknologi Sepuluh September.

Bappeda Prov. Kepri 2011. Laporan Pemetaan Potensi energi arus laut untuk pembangkit listrik di daerah Batam, Bintan dan Karimun.

BPS Prov. Kepri. 2012. Kepulauan Riau Dalam Angka.

Dishidros, 2007. Peta Arus Kawasan Indonesia Barat. Jakarta.

Lubis, 2013. Road Map Penelitian Dan Pengembangan Energi Arus Laut. PPPGL, Kementerian

ESDM. http://www.mgi.esdm.go.id/content/roadmap-penelitian-dan-pengembangan-energiarus-laut diakses 1 April 2013

P3TKP. 2012. Naskah Akademik Potensi dan Teknologi Energi Laut Indonesia. Pusat Pengkajian dan Perekayasaan Teknologi Kelautan dan Perikanan.

Sabella.2012. http://www.Sabella.fr diakses 1 April 2013

Suryansyah, Y. 2005. Kriteria teknologi Perikanan dan Kelautan untuk pengembangan pulau kecil di perbatasan (kasus: Pulau Laut, Kab. Natuna, Prov. Riau). Tesis, Sekolah Pascasarjana, Institut Pertanian Bogor. Bogor.

Yuningsih, A dan Masduki, A. 2011. Potensi Energi arus laut untuk pembangkit tenaga listrik di Kawasan Pesisir Flores Timur, NTT. Jurnal Ilmu dan Teknologi Kelautan Tropis, Vol. 3, No. 1, Hal. 13-25, Juni 2011. IPB. Bogor. 